\title{
Prolonged cough in children: a summary of the Belgian primary care clinical guideline
}

\author{
*Sophie Leconte ${ }^{\mathrm{a}}$, Dominique Paulus ${ }^{\mathrm{b}}$ Jan Degryse \\ ${ }^{a}$ Department of General Practice, Université Catholique de Louvain (UCL), Brussels, Belgium \\ ${ }^{b}$ Senior Expert Physician, Belgian Federal Health Care Knowledge Centre (KCE), Brussels, Belgium
}

Received 29th November 2007; revised version received 21st February 2008; accepted 24th February 2008; online 14th April 2008

\section{Summary}

Prolonged cough is a frequent problem in the community. Several studies in the school setting have found that as many as $4.8 \%$ to $10.4 \%$ of children suffer from prolonged cough.

There is no consensual definition of prolonged cough. In this guideline, we define prolonged cough as a daily cough lasting for more than three weeks. The literature review did not identify any quality study on the aetiology of prolonged cough in children in primary care. A diagnostic decision-tree based on the systematic literature review and expert opinion is proposed. Doctors should seek signs of any serious underlying condition. Chronic productive purulent cough should always be investigated. A careful evaluation of the impact of cough on the quality of life of the child is necessary. In absence of signs of specific underlying illness, coughing is generally a self-limiting condition. Symptomatic treatments have not yet been proven to be effective, and many of them may cause serious side effects. Their use should therefore be limited.

(c) 2008 General Practice Airways Group. All rights reserved.

S Leconte, et al. Prim Care Resp J 2008; 17(4): 206-211.

doi:10.3132/pcrj.2008.00028

Keyw ords guideline, primary care, general practice, children, paediatrics, cough, aetiology, diagnosis, treatment

See Appendix A at www.thepcrj.org

\section{Introduction}

Prolonged cough is a frequent problem in the community. Several studies in the school setting have found that up to $10.4 \%$ of children suffer from prolonged cough. ${ }^{1.5}$ Coughing causes insomnia and anxiety for parents, particularly since they can worry that their child might choke and die during the night. ${ }^{6}$

One study in the United Kingdom has shown that general practitioners (GPs) often prescribe antibiotics, bronchodilators, inhaled corticosteroids, or cromoglycate for prolonged cough. ${ }^{7}$ These children are often labelled as asthmatic. ${ }^{1,8}$

There is no consensual definition of prolonged cough. In this guideline, we define prolonged cough as a daily cough lasting for more than three weeks, because of the natural evolution of cough due to an upper respiratory tract infection (URTI). ${ }^{9}$

\section{Methods}

The literature was searched for studies on cough in children up to the age of 18. Two researchers performed independent systematic searches of the literature in the following databases:

- The websites of the Guidelines International Network and the National Guideline Clearinghouse were searched. Furthermore, guidelines were sought from various European countries: the National Institute for Health and Clinical Excellence (NICE-UK - www.nice.org.uk); the Société Scientifique De Médicine Générale (SSMG-B www.ssmg.be); Domus Medica (B - www.wvvh.be); the Belgian Antibiotic Policy Coordination Committee (BAPCOC - www.portal.health.fgov.be); and the Nederlands Huisartsen Genootschap (NHG-NI www.nhg.artsennet.nl). The search was performed in June 2005. Guidelines were assessed using the Agree criteria.

\footnotetext{
* Corresponding author: Dr Sophie Leconte, Department of General Practice, Université Catholique de Louvain (UCL), Avenue E.M ounier 53, 1200 Brussels, Belgium. Tel: +32 27645344 Fax: +32 27645327 E-mail: sophie.leconte@uclouvain.be
} 
- Searches of the Cochrane Library and the website of the Center for Reviews and Dissemination were performed up to May 2007.

- A search was performed on Medline from 1990 to June 2005 and on EMBASE from 1990 to January 2005. The main MeSH terms used were cough, pediatrics, child, complications, economics, diagnosis, aetiology, epidemiology, signs, chest, predictive value, mycoplasma, whooping cough, chlamydia, RCT, dust, allergy, and prevention. The authors used the EMTREE terms coughing and child (diagnosis, aetiology and epidemiology).

- Other sources such as Clinical Evidence, Folia Pharmacotherapeutica, Prescrire, the World Health Organisation website and the Belgian Public Health Institute's website (ww.iph.fgov.be) were also reviewed.

The results of the systematic search were discussed according to the scientific guidelines of the working group of the Société Scientifique de Medicine Générale (SSM G). The preliminary version of the guideline was submitted to two respiratory paediatricians. Four groups of GPs tested the final version of the guideline. Their remarks were included in the draft. The text was finally submitted to the Belgian Center for Evidence Based M edicine, which validated the guidelines after final changes.

Level of recommendations

Level A: - systematic review of randomised controlled trials (RCTs)

- meta-analysis

- more than 2 RCTs

Level B: - one RCT, other study, guideline

Level C: - expert opinion

\section{Results: summary of literature review on prolonged cough in children Aetiology}

The literature review did not identify any quality study on the aetiology of prolonged cough.

According to expert opinion and case series', the following aetiologies may be causes of prolonged cough but they are not based on studies in primary care settings: ${ }^{10}$

- Infections

Ten per cent of children still cough 25 days after an URTI. ${ }^{11}$ A succession of different infections or specific causal agents such as respiratory syncytial virus, adenovirus, Mycoplasma pneumoniae, and Chlamydia pneumoniae can be involved. ${ }^{12}$ Doctors should also bear in mind the possibility of pertussis ${ }^{13-15}$ and tuberculosis infections. ${ }^{16,17}$

- Asthma

Doctors should exercise caution when making the diagnosis of "cough variant asthma". Children in this category appear to have different characteristics than those with classic asthma, including a better prognosis. ${ }^{1,2,18-20}$

- Postnasal drip syndrome

- Environmental agents

Several studies have shown that passive smoking increases the incidence of cough and/or sinusitis in children. ${ }^{5,21-24} \mathrm{~A}$ relationship between factors in a child's indoor environment (nitric oxide, space heater, charcoal heater, kerosene firing, wood firing, mould) and cough has been found in observational studies. ${ }^{25-28}$

- Gastro-oesophageal reflux is often associated with chronic cough. 29,30

- Other causes

- foreign bodies

- immunodeficiency

- cystic fibrosis

- psychogenic cough

- congenital lung lesions, e.g., tracheomalacia, tracheooesophageal fistula)

- ciliary dyskinesia

\section{Diagnosis (see Figure 1)}

- Doctors should seek signs of any serious underlying condition:

G Neonatal onset of the cough

- Family history of lung disease

Serious upper respiratory tract infections

Important vomiting

- Dysphagia

- Abnormal voice or crying

- Focal thoracic abnormality

- Failure to thrive

- Clubbing

- Inspiratory stridor

- History:

Doctors should assess the importance of the symptom, its place in, and the repercussions on, the life of the child. Doctors should also inquire about the parents' anxieties and expectations. History taking should include asking about signs and symptoms of the most frequent aetiologies: postnasal drip syndrome, asthma, respiratory tract infections and gastro-oesophageal reflux. Environmental factors such as passive smoking exposure and the epidemic context should be noted.

- Clinical examination should include: ${ }^{31,32}$

- respiratory rate

- signs of dyspnoea

- signs of atopy

- height, weight

- temperature

- ear, nose and throat examination

- chest auscultation 
Figure 1. Decision-tree based on the systematic literature review and expert opinion.

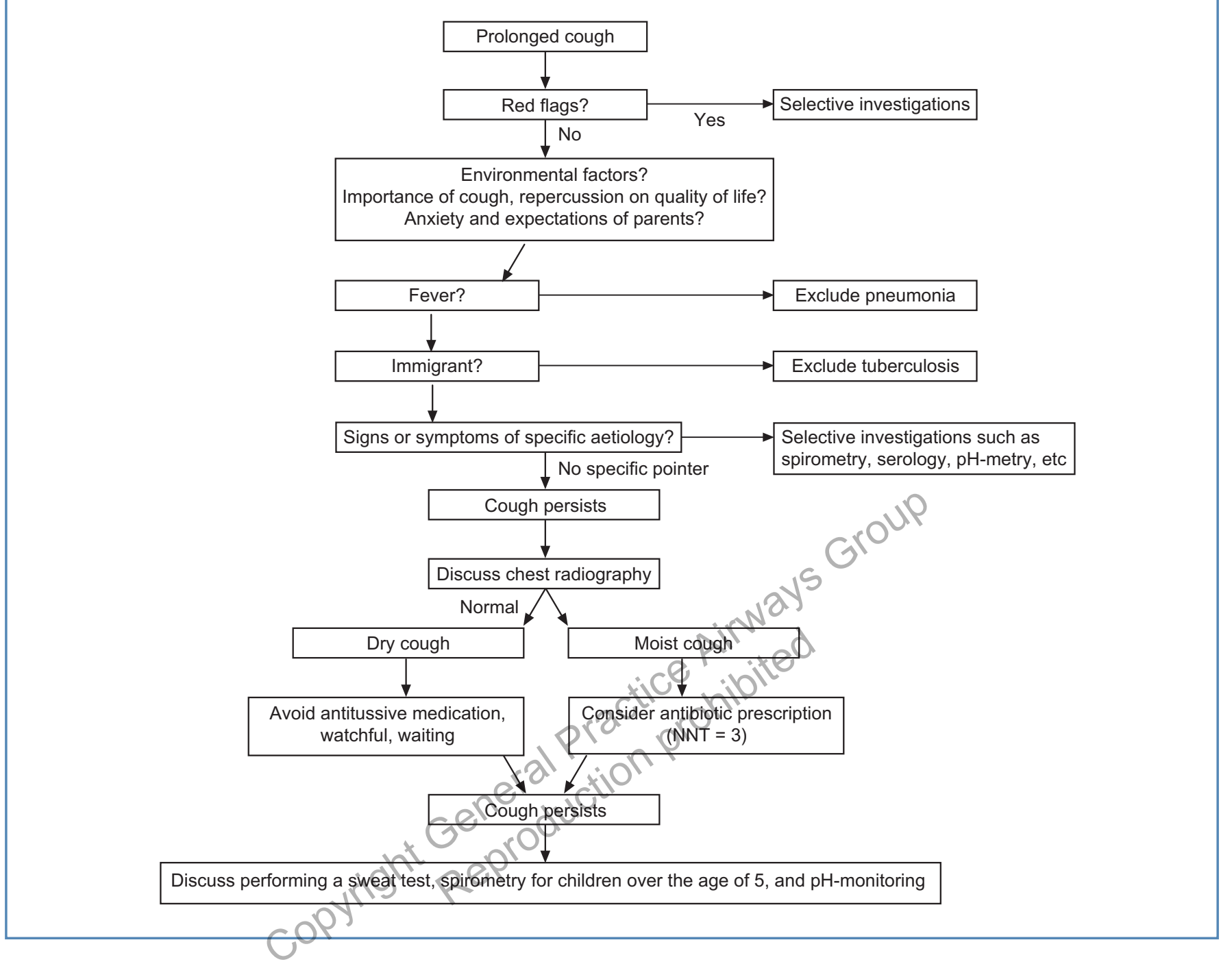

- Investigations:

Doctors should order tests depending on their clinical hypotheses.

Suspicion of infection:

Serology for Mycoplasma pneumoniae and serology plus PCR for Bordetella pertussis could be useful, ${ }^{14,33}$ (EBM level B). According to expert opinion, if there is a suspicion of pneumonia, a chest X-ray should be performed, (EBM level C).

There is no evidence of the usefulness of determining the CRP concentration or leukocyte count in chronic cough.

Suspicion of asthma:

- Spirometry with reversibility should be done if the child is older than 5 years, (EBM level B).

- Peak flow monitoring is useful in order to diagnose or exclude asthma if the spirometry results are normal. Peak flow monitoring is also useful for the follow-up of asthma. ${ }^{32} \mathrm{~A}$ single value is not enough: the variability of the peak flow should be assessed, ${ }^{34}$ (EBM level B).
- Diagnostic trial: some authors and guidelines recommend trying inhaled $\beta$-agonists or inhaled corticosteroids (ICS) and assessing responsiveness. ${ }^{18,31,34-36}$ Such trials are particularly useful in young children when spirometry is not available. However, there is not sufficient evidence to recommend diagnostic trials systematically: responsiveness is not specific for asthma.

Suspicion of sinusitis:

- Sinus radiography:

- before the age of six years, radiography is unnecessary ( $88 \%$ of $\mathrm{X}$-rays are positive if there is a clinical history of sinusitis).

- after the age of six, radiography can sometimes be useful to exclude sinusitis, ${ }^{37}$ (EBM level B).

- Sinus scanning is only necessary in rare cases when a complication is suspected or if surgery is warranted. ${ }^{38}$

Suspicion of gastro-oesophageal reflux:

$\mathrm{pH}$-monitoring is the most useful test to assess the temporal 
association between reflux and cough, ${ }^{39}$ (EBM level B). Chest radiography:

There is not sufficient evidence to recommend chest radiography in all cases. It can be useful when specific lung pathology is suspected or in unclear cases which do not improve, (EBM level C).

\section{Treatment}

\section{A. No specific aetiology}

At present, no treatment has proven efficacy for the treatment of cough in children when there is no known aetiology (see Appendix A, available online at www.thepcrj.org). Several studies have shown that placebos are effective. ${ }^{40-42}$ Doctors should explain to the parents that the cough is very likely to resolve spontaneously. No treatment is required unless the cough is painful, interferes with sleep, or causes insomnia, vomiting or fatigue. ${ }^{43,44}$

The first recommendation is to avoid passive smoking and any other irritant. If the doctor still decides to prescribe medication, consideration should be given to the contraindications and potential side effects of the medication. Combination products should be avoided.

B. Cough linked to a specific aetiology

Cough linked to asthma

Guidelines ${ }^{31,34}$ recommend treating the cough with a ßagonist and/or ICS. The maximal effect of symptomatic treatment with ICS is after six to eight weeks of treatment. ${ }^{30}$ Cough associated with gastro-oesophageal reflux

There are no studies on the management of cough associated with gastro-oesophageal reflux in children. 3 . There is no evidence of the efficacy of proton pump inhibitors on cough linked to gastro-oesophageal reflux.45

Cough due to pertussis

Salbutamol, dexamethasone, specific immunoglobulin and diphenhydramine proved to have no efficacy in the symptomatic treatment of whooping cough. ${ }^{46}$ However, expert opinion recommends that $\beta$-agonists are effective in infections such as pertussis with bronchial hyperreactivity.

C. Risks and contraindications of antitussive drugs Formal contraindications

Before the age of one year, no antitussive medicine should be prescribed. Between the ages of one and two years, antitussive use should be exceptional, and requires prior medical evaluation. Dextromethorphan, noscapine, and phenothiazine derivatives are contraindicated. Between two and six years of age, any prescription should be limited.

Because of possible neurological side effects, camphor must be avoided, and eucalyptus and menthol should be used with caution. ${ }^{47}$

We did not find any RCTs studying the efficacy of camphor, menthol, eucalyptus, clobutinol or dimethoxane and chloral hydrate for cough in children.

\section{Surveillance}

If a treatment is prescribed, a follow-up evaluation is necessary to avoid unnecessary prolonged use of medications. If bronchodilators are prescribed, the doctor should see the patient after 15 days. Inhaled steroids may take as long as six weeks to be fully effective.

\section{Discussion}

In summary, in the absence of signs of specific underlying illness, coughing is generally a self-limiting condition. Symptomatic treatments have not yet been proven to be effective, and many of them may cause serious side effects. Their use should therefore be limited.

Our review showed a paucity of evidence-based literature on this topic. Two guidelines were published in 2006. ${ }^{48,49}$ Their recommendations are often based on expert opinions and on studies done in tertiary care settings. There are no epidemiologic studies of the aetiology of prolonged cough in children in primary care, and serious diseases are probably less frequent in primary care than in secondary or tertiary settings.

These guidelihes recommend at least chest radiography and spirometry if the patient's age is appropriate. There is no evidence that these tests are always necessary for patients with prolonged cough in primary care. This guideline has also asserted that chronic productive purulent cough should always be investigated to document the presence or absence of bronchiectasis and to identify underlying and treatable causes such as cystic fibrosis and immune deficiency. However, there is no strong evidence in the literature that post-nasal drip syndrome might cause cough, even though it could represent a common cause of productive cough in primary care.

Invasive investigations could probably therefore be avoided in the absence of specific 'red flags' or in the absence of improvement. Primary care physicians have to keep in mind the subjectivity of the complaint of cough when prescribing investigations. The same description may cover coughs with a wide range of frequency and intensity.

No treatment for non-specific cough has proved to have any efficacy. A careful evaluation of the impact of cough on the quality of life of the child is necessary. Doctors should also explore the expectations and anxieties of parents about their child's cough. In such cases, reassurance and watchful waiting is the best approach. If the doctor still decides to prescribe a medication, a simple sweet syrup can be a safe solution.

This literature review showed the lack of studies on prolonged cough in primary care, and the fact that more studies are needed. Firstly, prospective morbidity studies and aetiological studies should be conducted in primary care settings to determine the frequency of cough and the probable aetiologies. A study of morbidity and aetiology is 
currently underway in our department. Secondly, studies on the natural evolution of prolonged cough of different aetiologies would help doctors to better inform and manage their patients. Further research could also evaluate the effectiveness and usefulness of therapeutic trials in the diagnostic work-up. Thirdly, research on the treatment of non-specific cough with valid outcome measures is especially warranted. The challenge for all therapeutic research on cough is the validation of automated measurement instruments. We are currently validating a cough counter that measures cough frequency.

\section{Acknow ledgement}

This article is a summary of a Belgian primary care guideline on prolonged cough in children. This guideline was elaborated in conjunction with the scientific society of general practice and has been validated by the Belgian Center for Evidence Based Medicine in June 2007.

\section{Conflict of interest declaration}

None to declare.

\section{References}

1. Faniran AO, Peat JK, Woolcock AJ. Persistent cough: is it asthma? Arch Dis Child 1998;79:411-14.

2. Ninan TK, Macdonald L, Russell G. Persistent nocturnal cough in childhood: a population based study. Arch Dis Child 1995;73:403-07.

3. Faniran AO, Peat JK, Woolcock AJ. Measuring persistent cough in children in epidemiological studies. Chest 1999;115:434-9.

4. Kelly YJ, Brabin BJ, Milligan PJ, et al. Clinical significance of cough and wheeze in the diagnosis of asthma. Arch Dis Child 1996;75:489-93.

5. Austin JB, Russell G. Wheeze, cough, atopy, and indoor environment in the Scottish Highlands. Arch Dis Child 1997;76:22-6.

6. Cornford CS, Morgan M, Ridsdale L. Why do mothers consalt when their children cough? Fam Pract 1993;10:193-6.

7. Picciotto $A$, Hubbard $M$, Sturdy $P$, et al Prescribing for persistent cough in children. Respir Med 1998;92:638-41.

8. Thomson F, Masters IB, Chang AB. Persistent cough in children and the overuse of medications. J Paediatr Child Health 2002;38:578-81.

9. Cazzato T, Pandolfini C, Campi R. et al. Drug prescribing in out-patient children in southern Italy. Europ J of Clin Pharmacology 2004;57(8): 611-16.

10. Brémont F, Micheau P, Le Roux P, Brouard J, Pin I, Fayon M. Etiology of chronic cough in children: analysis of 100 cases. Arch Pediatr 2001;8 Suppl 3: 645-9.

11. Hay AD, Wilson A, Fahey $T$, et al. The duration of acute cough in pre-school children presenting to primary care: a prospective cohort study. Fam Pract 2003;20:696-705.

12. Velissariou IM, Kafetzis DA. Chronic cough in children: recent advances. Expert Rev Anti Infect Ther 2004;2:111-17.

13. de Greeff SC, Schellekens JF, Mooi FR, de Melker HE. [Effect of vaccination against pertussis on the incidence of pertussis in The Netherlands, 1996-2003]. Ned Tijdschr Geneeskd 2005;149:937-43.

14. Crowcroft NS, Britto J. Whooping cough - a continuing problem. BMJ 2002;324:1537-8

15. Brown MO, St Anna L, Ohl M. Clinical inquiries. What are the indications for evaluating a patient with cough for pertussis? J Fam Pract 2005;54:74-6.

16. Morice AH, Fontana GA, Sovijarvi AR, et al. The diagnosis and management of chronic cough. Eur Respir J 2004;24:481-92.

17. Frieden TR, Sterling TR, M unsiff SS, et al. Tuberculosis. Lancet 2003;362:887-99.

18. Keeley $D$ J, Silverman $M$. Issues at the interface between primary and secondary care in the management of common respiratory disease. 2: Are we too ready to diagnose asthma in children? Thorax 1999;54:625-8.

19. Wright AL, Holberg $\mathrm{CJ}$, Morgan WJ, et al. Recurrent cough in childhood and its relation to asthma. Am J Respir Crit Care Med 1996;153:1259-65.

20. Timonen KL, Pekkanen J, Korppi $M$, et al. Prevalence and characteristics of children with chronic respiratory symptoms in eastern Finland. Eur Respir J 1995;8:1155-60.

21. Somerville SM, Rona RJ, Chinn S. Passive smoking and respiratory conditions in primary school children. J Epidemiol Community Health 1988;42:105-10.

22. Charlton A. Children's coughs related to parental smoking. Br Med J (Clin Res Ed) $1984 ; \mathbf{2 8 8}: 1647-9$

23. Kakish KS, Mahafza T, Batieha A, Ekteish F, Daoud A. Clinical sinusitis in children attending primary care centers. Pediatr Infect Dis J 2000;19:1071-4.

24. Withers NJ, Low L, Holgate ST, Clough JB. The natural history of respiratory symptoms in a cohort of adolescents. Am J Respir Crit Care Med 1998; 158:352-7.

25. Belanger $\mathrm{K}$, Beckett $\mathrm{W}$, Triche $\mathrm{E}$, et al. Symptoms of wheeze and persistent cough in the first year of life: associations with indoor allergens, air contaminants, and maternal history of asthma. Am J Epidemiol 2003;158:195 202.

26. Gent JF, Ren P, Belanger K, et al. Levels of household mold associated with respiratory symptoms in the first year of life in a cohort at risk for asthma. Environ Health Perspect 2002;110:A781-A786.

27. Jaakkola JJ, Jaakkola N, Ruotsalainen R. Home dampness and molds as determinants of respiratory symptoms and asthma in pre-school children. J Expo AnakEnviron Epidemiol 1993;3 Suppl 1:129-42.

28. Triche EW, Belanger K, Beckett W, et al. Infant respiratory symptoms associated with indoor heating sources. Am J Respir Crit Care Med 2002;166:1105-11

29. Irwin RS, Curley FJ, French CL. Chronic cough. The spectrum and frequency of causes, key components of the diagnostic evaluation, and outcome of specific therapy. Am Rev Respir Dis 1990;141:640-7.

30. Mello CJ, Irwin RS, Curley FJ. Predictive values of the character, timing, and complications of chronic cough in diagnosing its cause. Arch Intern Med 1996;156:997-1003.

31. Stoffelen H, De scampheleire L, Van Peer W. Asthma bij kinderen. Aanbeveling voor goede medisch Praktijvoering. WVVH. 1999. berchem 26 p, www.wwh.be

32. National Institutes of health, national heart lung and blood institute. Guidelines for the diagnosis and management of asthma, expert panel report 2. NIH Publication No. 97-4051. Bethesda, MD: U.S.1997. http://www.nhlbi.nih.gov/ guidelines/archives/epr-2/index.htm. Last reached novembre 26th 2007.

33. Tozzi $A E$, Celentano LP, Ciofi degli Atti ML, et al. Diagnosis and management of pertussis. CM AJ 2005;172:509-15.

34. National Heart, Lung and Blood Institute NHLBI. GINA, Global Initiative for Asthma. Global strategy for asthma management and prevention. Bethesda (MD): Global Initiative for Asthma (GINA). 2006. www.ginasthma.com.

35. Cochran D. Diagnosing and treating chesty infants. A short trial of inhaled corticosteroid is probably the best approach. BMJ 1998;316:1546-7.

36. Irwin RS, Boulet LP, Cloutier M. Managing cough as a defense mechanism and as a symptom. Chest 1998;114:113S-81S.

37. Weinstein AG. Crying-induced bronchospasm in childhood asthma. J Asthma 1984;21:161-5

38. AAP, American Academy of Pediatrics. Clinical practice guideline: management of sinusitis. Pediatrics 108(3). 2001.

39. Rudolph CD, Mazur LJ, Liptak GS, et al. Guidelines for evaluation and treatment of gastroesophageal reflux in infants and children: recommendations of the North American Society for Pediatric Gastroenterology and Nutrition. J Pediatr Gastroenterol Nutr 2001;32 Suppl 2:S1-31.

40. Eccles R. The powerful placebo in cough studies? Pulm Pharmacol Ther 2002; 15:303-08.

41. Taylor JA, Novack AH, Almquist JR, et al. Efficacy of cough suppressants in 
children. J Pediatr 1993;122:799-802.

42. Davies MJ, Fuller P, Picciotto A, et al. Persistent nocturnal cough: randomised controlled trial of high dose inhaled corticosteroid. Arch Dis Child 1999;81:38-44.

43. American Academy of Pediatrics. Committee on Drugs. Use of codeine- and dextromethorphan-containing cough remedies in children. Pediatrics 1997; 99:918-20.

44. David V, Siret D. [Symptomatic treatment of cough in children]. Arch Pediatr 2001;8 Suppl 3:655-8.

45. Chang AB, Lasserson TJ, Gaffney J, et al. Gastro-oesophageal reflux treatment for prolonged non-specific cough in children and adults. Cochrane Database Syst Rev 2005;CD004823. http://www3.interscience.wiley.com/cgi-bin/ mrwhome/106568753/HOME

46. Pillay V, Swingler G. Symptomatic treatment of the cough in whooping cough. Cochrane Database Syst Rev 2003;CD003257. http://www3.interscience.wiley. com/cgi-bin/mrwhome/106568753/HOME

47. La revue prescrire. Vicks babybalm: cosmétique à risque. Prescrire 2005;257:22-3.

48. Chang $A B$, Glomb WB. Guidelines for evaluating chronic cough in pediatrics: ACCP evidence-based clinical practice guidelines. Chest 2006;129:260S-83S.

49. Chang $A B$, Landau $L I$, van Asperen PP, et al. Cough in children: definitions and clinical evaluation. Med J Aust 2006;184:398-403.

The following references relate to Appendix A, available at www.thepcrj.org

50. Schroeder K, Fahey T. Should we advise parents to administer over the counter cough medicines for acute cough? Systematic review of randomised controlled trials. Arch Dis Child 2002;86:170-5.

51. Paul IM, Yoder KE, Crowell KR, et al. Effect of dextromethorphan, diphenhydramine, and placebo on nocturnal cough and sleep quality for coughing children and their parents. Pediatrics 2004;114:e85-e90.

52. Chang A, Peake J, McElrea M. Anti-histamines for prolonged non-specific cough in children. Cochrane Database Syst Rev 2006;3:CD005604. http://www3.interscience.wiley.com/cgi-bin/mrwhome/106568753/HOME

53. Chang, AB. Inhaled anti-cholinergics for prolonged non-specific Cough in children. Cochrane database 2004., CD004358. http://www3.interscience. wiley.com/cgi-bin/mrwhome/106568753/HOME

54. Chang AB, Marchant JM, M CKean M, et al. Inhaled cromones for hon specific cough in children. Cochrane database 2003. http: I/Www3. interscience.
wiley.com/cgi-bin/mrwhome/106568753/HOME

55. Smucny JJ. Are beta2-agonists effective treatment for acute bronchitis or acute cough in patients without underlying pulmonary disease? A systematic review. J Fam Pract 2001;50(11):945-51.

56. Tomerak AA, Vyas $H$, Lakenpaul $M$, et al. Inhaled beta2-agonists for treating non-specific chronic cough in children. Cochrane Database Syst Rev 2005;CD005373. http://www 3.interscience.wiley.com/cgi-bin/mrwhome/ 106568753/HOME

57. Tomerak AA, McGlashan JJ, Vyas HH, et al. Inhaled corticosteroids for nonspecific chronic cough in children. Cochrane Database Syst Rev 2005;CD004231. http://www3.interscience.wiley.com/cgi-bin/mrwhome/ 106568753/HOME

58. Chang AB, Phelan PD, Carlin JB, et al. A randomised, placebo controlled trial of inhaled salbutamol and beclomethasone for recurrent cough. Arch Dis Child 1998;79:6-11.

59. Chang $A B$, Winter $D, A c$ orth JP. Leukotriene receptor antagonist for prolonged non-specific cough in children. Cochrane Database Syst Rev 2006;CD005602. http://www3.interscience.wiley.com/cgi-bin/mrwhome/ 106568753/HOME

60. Chang AB, Halstead RA, Petsky HL. Methylxanthines for prolonged non-specific cough in children. Cochrane Database Syst Rev 2005;CD005310. http://www3. interscience.wiley.com/cgi-bin/mruhome/106568753/HOME

61. Marchant JM, M orris P, Gaffney JT, et al. Antibiotics for prolonged moist cough in children. Cochrane Batabase Syst Rev 2005;CD004822. http://www3. interscience.wiley.com/cgi-bin/mrwhome/106568753/HOM E

62. Altunaiji S, KuKuruzovic R, Curtis N, et al. Antibiotics for whooping cough (pertussis). Cochrane Database Syst Rev 2005;CD004404. http://www3. interscience. willey.com/cgi-bin/mrwhome/106568753/HOM E

63. Gavranich B, Chang AB. Antibiotics for community acquired lower respiratory tractinfections (LRTI) secondary to Mycoplasma pneumoniae in children. Cochrane Database Syst Rev 2005;CD004875. http://www3.interscience. wiley.com/cgi-bin/mrwhome/106568753/HOME

64. Donnelly D, Everard M, Chang A. Indoor air modification interventions for prolonged non-specific cough in children. Cochrane Database Syst Rev 2006;3:CD005075. http://www3.interscience.wiley.com/cgi-bin/mrwhome/ 106568753/HOME

Available online at http://w w w.thepcrj.org 


\section{Appendix A. Summary of systematic reviews and RCTs of effects of medications on cough in children.}

\begin{tabular}{|c|c|c|c|c|c|c|}
\hline Reference & & Medication & Nos of studies & Population studied & Outcome & Results \\
\hline Schroeder $2004^{50}$ & Systematic review & $\begin{array}{l}\text { 1. Dextromethorphan } \\
1.5 \mathrm{mg} / 5 \mathrm{ml} \text { for } \\
\text { children under } 7 \text { years } \\
\text { and } 10 \mathrm{ml} \text { three times } \\
\text { daily for older children } \\
\text { in one arm, and } \\
\text { dextromethorphan } \\
\text { with salbutamol } \\
0.2 \mathrm{mg} / 5 \mathrm{ml} \text { before } \\
7 \text { years, and } 10 \mathrm{ml} \\
\text { for older children in } \\
\text { the other arm. } \\
2 . \text { Dextromethorphan } \\
15 \mathrm{mg} / 5 \mathrm{ml}\end{array}$ & $\begin{array}{l}2: 1 / n=50 \\
2 / n=57\end{array}$ & $\begin{array}{l}\text { 1. Children, mean } \\
\text { age } 3.8 \text { years with } \\
\text { acute cough } \\
\text { 2. Children aged } \\
\text { between } 18 \text { months } \\
\text { and } 12 \text { years with } \\
\text { nocturnal cough due } \\
\text { to URTI }\end{array}$ & $\begin{array}{l}\text { 1. Scales from } 0 \text { to } 3 \\
\text { for cough frequency } \\
\text { and severity } \\
\text { 2. Cough scores of } \\
0 \text { to } 4\end{array}$ & $\begin{array}{l}\text { No difference } \\
\text { between groups } \\
\text { 2. A mean reduction } \\
\text { in cough score of } 2.1 \\
\text { versus } 2.2 \text { in placebo } \\
\text { group; } p=0.97\end{array}$ \\
\hline Paul $2004^{51}$ & $\mathrm{RCT}$ & Dextromethorphan & $n=100$ & $\begin{array}{l}\text { Children aged } \\
\text { between } 2 \text { and } \\
18 \text { years, with } \\
\text { URTI }\end{array}$ & $\begin{array}{l}\text { Subjective parental } \\
\text { assessment of cough } \\
\text { and sleep difficulty }\end{array}$ & $\begin{array}{l}\text { No statistically } \\
\text { significant difference } \\
\text { of improvement on } \\
\text { night cough scores } \\
\text { between active and } \\
\text { placebo groups }\end{array}$ \\
\hline Schroeder $2004^{50}$ & Systematic review & $\begin{array}{l}\text { Codeine } \\
(10 \mathrm{mg} / 5 \mathrm{ml})\end{array}$ & $1, n=57$ & $\begin{array}{l}\text { children aged } \\
\text { between } 18 \text { months } \\
\text { and } 12 \text { years with } \\
\text { nocturnal cough } \\
\text { due to URTI }\end{array}$ & $\begin{array}{l}\text { Cough scores of } \\
0 \text { to } 4\end{array}$ & $\begin{array}{l}\text { Mean reduction in } \\
\text { cough score in } \\
\text { codeine group } 2.2 \text {, } \\
\text { versus placebo group } \\
2.2, p=0.52\end{array}$ \\
\hline Schroeder $2004^{50}$ & Systematic review & $\begin{array}{l}\text { Mucolytic } \\
\text { (Letosteine, } 25 \mathrm{mg} \\
\text { three times daity) }\end{array}$ & $\begin{array}{l}1 \text {, but low } \\
\text { quality }(n=40)\end{array}$ & $\begin{array}{l}\text { Age range } 2 \text { to } 12 \\
\text { years with acute } \\
\text { febrile bronchitis }\end{array}$ & $\begin{array}{l}\text { Cough score from } \\
0 \text { to } 3\end{array}$ & $\begin{array}{l}\text { Difference between } \\
\text { groups ranging from } \\
0.1 \text { to } 0.3 \text { in favour } \\
\text { of treatment } \\
\text { between days } 4 \text { and } \\
10(p<0.01)\end{array}$ \\
\hline Schroeder $2004^{50}$ & Systematic review & Expectorant & No studies & & & \\
\hline Chang $2006^{52}$ & Systematic review & $\begin{array}{l}\text { Anti-histamines } \\
\text { 1. Pimethixene } \\
\text { 2. Cetirizine } \\
\text { 3. Ketotifen }\end{array}$ & $\begin{array}{l}\text { 3 RCTs, with } \\
\text { heterogeneity: } \\
\text { 1. } n=49 \\
\text { 2. } n=20 \\
\text { 3. } n=113\end{array}$ & $\begin{array}{l}\text { 1. Children aged } \\
\text { between } 3 \text { and } 17 \\
\text { years with hay fever } \\
\text { 2. Children with } \\
\text { cough associated with } \\
\text { allergic } \\
\text { rhinoconjunctivitis } \\
\text { 3. Children aged } \\
\text { between } 6 \text { and } 36 \\
\text { months with prolonged } \\
\text { cough or wheeze }\end{array}$ & $\begin{array}{l}\text { - Parental } \\
\text { questionnaire } \\
\text { - Cough diary score }\end{array}$ & $\begin{array}{l}2 \text { studies with no } \\
\text { effect, } 1 \text { study in } \\
\text { favour of Cetirizine, } \\
\text { which reduces cough } \\
\text { intensity ( } p<0.05 \text { ) } \\
\text { and frequency } \\
(p<0.01) \text {. }\end{array}$ \\
\hline Schroeder $2004^{50}$ & Systematic review & $\begin{array}{l}\text { Anti-histamines. } \\
\text { Clemastine fumarate } \\
\text { versus } \\
\text { Chlorpheniramine } \\
\text { maleate syrup }\end{array}$ & 1 study, $n=143$ & $\begin{array}{l}\text { Age range } 1.5 \text { to } \\
60 \text { months with } \\
\text { common cold } \\
\text { Symptom score }\end{array}$ & Cough improved in & $\begin{array}{l}39.6 \% \text { in the } \\
\text { treatment group } \\
\text { compared with } 27.6 \\
\% \text { in the placebo } \\
\text { group; } p=0.2\end{array}$ \\
\hline
\end{tabular}


Appendix A. Summary of systematic reviews and RCTs of effects of medications on cough in children continued

\begin{tabular}{|c|c|c|c|c|c|c|}
\hline Reference & & Medication & Nos of studies & Population studied & Outcome & Results \\
\hline Paul $2004^{51}$ & RCT & Diphenhydramine & $n=100$ & $\begin{array}{l}\text { Acute night cough } \\
\text { due to URTI in } \\
\text { children aged } \\
\text { between } 2 \text { and } \\
18 \text { years }\end{array}$ & $\begin{array}{l}\text { Subjective parental } \\
\text { assessment of cough } \\
\text { and sleep difficulty }\end{array}$ & $\begin{array}{l}\text { No statistical } \\
\text { difference of } \\
\text { improvement } \\
\text { between active and } \\
\text { placebo groups }\end{array}$ \\
\hline Schroeder $2004^{50}$ & Systematic review & $\begin{array}{l}\text { Antihistamine- } \\
\text { decongestant } \\
\text { 1. Brompheniramine } \\
\text { maleate } 2 \mathrm{mg} / 5 \mathrm{ml} \\
\text { and Phenylpropanol- } \\
\text { amine hydrochloride } \\
12.5 \mathrm{mg} / 5 \mathrm{ml} \text { every } \\
4 \text { hours } \\
\text { 2. Brompheniramine } \\
\text { maleate } 4 \mathrm{mg} / 5 \mathrm{ml} \text {, } \\
\text { Phenylephrine } \\
5 \text { mg/5 ml, } \\
\text { Propanolamine } \\
5 \mathrm{mg} / 5 \mathrm{ml} \text {, three } \\
\text { times daily }\end{array}$ & 2 studies, $n=155$ & $\begin{array}{l}\text { Preschool children } \\
\text { ( } 6 \text { months to } 5 \text { years) } \\
\text { with URTI }\end{array}$ & Cough score & $\begin{array}{l}\text { No effect } 1 / \text { mean } \\
\text { cough score } 4.67 \\
\text { (active treatment) } \\
\text { versus } 4.57 \text { (placebo); } \\
p=0.53 . \text { M ore } \\
\text { children were asleep } \\
\text { in the treatment } \\
\text { group. } \\
2 . \text { Improvement of } \\
67 \% \text { in the active } \\
\text { treatment group, } \\
58 \% \text { in the placebo } \\
\text { group and } 70 \% \text { in } \\
\text { the no treatment } \\
\text { group ( } p=0.5 \text { and } \\
0.8, \text { respectively) }\end{array}$ \\
\hline Chang $2004^{53}$ & Systematic review & $\begin{array}{l}\text { Inhaled } \\
\text { anticholinergics }\end{array}$ & or & & & \\
\hline Chang $2003^{54}$ & Systematic review & Inhaled cromones & & & & \\
\hline Smucny $2004^{55}$ & Systematic review & $\begin{array}{l}\beta 2 \text {-agonists } \\
\text { (Albuterol syrup } 0 . \\
\text { mg/kgevery } 8 \text { hours } \\
\text { or Salbutamol } 1 \mathrm{mg} \\
\text { every } 8 \text { hours before } \\
\text { the age of } 7 \text { and } 2 \\
\text { mg every } 8 \text { hours for } \\
\text { older children) }\end{array}$ & & $\begin{array}{l}\text { Acute cough in } \\
\text { children aged } \\
\text { between } 1 \text { and } \\
10 \text { years }\end{array}$ & Cough score & $\begin{array}{l}\text { Standardised mean } \\
\text { difference of cough } \\
\text { score }=0.35(-0.05 \text {, } \\
0.76) \text {. } \\
\text { RR of side effects } \\
6.76 \text { with } 95 \% \mathrm{Cl} \text { : } \\
0.86-53.12)\end{array}$ \\
\hline Tomerak $2005^{56}$ & Systematic review & $\begin{array}{l}\beta 2 \text {-agonists } \\
\text { (Salbutamol } 200 \mu \mathrm{g} \\
\text { twice a day) }\end{array}$ & 1 trial, $n=43$ & $\begin{array}{l}\text { Children aged } \\
\text { between } 6 \text { and } 17 \\
\text { years with chronic } \\
\text { non-specific cough }\end{array}$ & $\begin{array}{l}\text { Cough frequency } \\
\text { (cough meter) and } \\
\text { subjective cough } \\
\text { score }\end{array}$ & $\begin{array}{l}\text { No effect, but the } \\
\text { confidence intervals } \\
\text { are wide. } \\
\text { Weighted mean } \\
\text { difference in cough } \\
\text { frequency/24h = - } 11 \\
(95 \% \mathrm{Cl} \text { : } \\
150.22-128.82)\end{array}$ \\
\hline Tomerak $2005^{57}$ & Systematic review & Inhaled steroids & 2 RCTs (see below) & Children & & \\
\hline Davies $1999^{42}$ & $\mathrm{RCT}$ & $\begin{array}{l}\text { Fluticasone } 1 \mathrm{mg} \\
\text { twice daily for } 3 \text { days } \\
\text { and } 500 \mu \mathrm{g} \text { twice } \\
\text { daily for } 11 \text { days }\end{array}$ & $n=50$ & $\begin{array}{l}\text { Children aged } \\
\text { between } 1 \text { and } 10 \\
\text { years with persistent } \\
\text { night time cough }\end{array}$ & $\begin{array}{l}\text { Cough frequency } \\
\text { assessed by video or } \\
\text { audio system }\end{array}$ & $\begin{array}{l}\text { Significant reduction } \\
\text { in treatment group } \\
\text { More than } 75 \% \\
\text { improvement at days } \\
15-18, \text { OR }=4,55 \\
(95 \% \mathrm{Cl} 1.33-15.57)\end{array}$ \\
\hline
\end{tabular}


Appendix A. Summary of systematic reviews and RCTs of effects of medications on cough in children continued

\begin{tabular}{|c|c|c|c|c|c|c|}
\hline Reference & & Medication & Nos of studies & Population studied & Outcome & Results \\
\hline
\end{tabular}

\begin{tabular}{|c|c|c|c|c|c|c|}
\hline Chang $2006^{59}$ & Systematic review & $\begin{array}{l}\text { Leukotriene receptor } \\
\text { antagonist }\end{array}$ & No RCTs included & $\begin{array}{l}\text { Children with } \\
\text { non-specific cough }\end{array}$ & & \\
\hline Chang $2005^{60}$ & Systematic review & M ethylxanthines & $\begin{array}{l}\text { No RCTS, } 1 \text { non- } \\
\text { randomised trial }\end{array}$ & $\begin{array}{l}\text { Children with } \\
\text { non-specific cough }\end{array}$ & & \\
\hline Marchant $2005^{61}$ & $\begin{array}{l}\text { Systematic review, } \\
\text { meta-analysis }\end{array}$ & $\begin{array}{l}\text { Antibiotics } \\
\text { (erythromycin } \\
50 \mathrm{mg} / \mathrm{kg} / \text { day versus } \\
\text { placebo or } \\
\text { amoxicillin/ clavulanic } \\
\text { acid } 20 \mathrm{mg} / \mathrm{kg} / \text { day } \\
\text { versus placebo) }\end{array}$ & $\begin{array}{l}2 \text { RCTs, but low } \\
\text { quality ( } n=140 \text { ) }\end{array}$ & $\begin{array}{l}\text { Children with } \\
\text { persistent moist } \\
\text { cough }\end{array}$ & $\begin{array}{l}\text { Proportion of } \\
\text { children not cured } \\
\text { at follow up } \\
\text { Proportion of } \\
\text { children who } \\
\text { required further } \\
\text { antibiotics }\end{array}$ & $\begin{array}{l}\text { More children are } \\
\text { cured with } \\
\text { antibiotics: OR } 0.13 \\
(95 \% \mathrm{Cl}: 0.06 \text { to } \\
0.32), \mathrm{NNT}=3(95 \% \\
\mathrm{Cl} 2-4) \\
\text { More children } \\
\text { required further } \\
\text { antibiotics in the } \\
\text { placebo group OR: } \\
0.10 \text { (95\% Cl: } \\
0.03-0.34), \mathrm{NNT}=4 \\
(95 \% \mathrm{Cl}: 3-5)\end{array}$ \\
\hline Altunaiji $2005^{62}$ & Systematic review & $\begin{array}{l}\text { Antibiotics } \\
\text { (azithromycin } 3 \text { days } \\
\text { or clarythromycin } 7 \\
\text { days or erythromycin } \\
7 \text { days versus } 10 \text { to } \\
14 \text { days erythromycin }\end{array}$ & 13 RCTs ( $n=2197)$ & Whooping cough & $\begin{array}{l}\text { Bordetella pertussis } \\
\text { eradication from the } \\
\text { nasopharynx }\end{array}$ & $\begin{array}{l}\text { No difference } \\
\text { between short and } \\
\text { long treatment for } \\
\text { eradication of } \\
\text { Bordetella pertussis } \\
\mathrm{RR}=1.02 \text { ( } 95 \% \mathrm{Cl} \text { : } \\
0.98-1.05 \text { ) but fewer } \\
\text { side effects with } \\
\text { short treatment } \\
\mathrm{RR}=0.66(95 \% \mathrm{Cl} \text { : } \\
0.52-0.83) \text {. }\end{array}$ \\
\hline Donnelly $2006^{64}$ & Systematic review & $\begin{array}{l}\text { Indoor air } \\
\text { modification } \\
\text { intervention }\end{array}$ & No RCTs & $\begin{array}{l}\text { Prolonged cough in } \\
\text { children }\end{array}$ & & \\
\hline Chang $2005^{45}$ & Systematic review & $\begin{array}{l}\text { Gastro-oesophageal } \\
\text { reflux treatment }\end{array}$ & $\begin{array}{l}3 \text { studies in children } \\
\text { but no studies that } \\
\text { can be included }\end{array}$ & $\begin{array}{l}\text { Prolonged } \\
\text { non-specific cough } \\
\text { in children }\end{array}$ & & \\
\hline
\end{tabular}

